\title{
Protein Synthesis during Germination of Peronospora tabacina Conidia: an Examination of the Events Involved in the Initiation of Germination
}

\author{
By D. W. HOLLOMON* \\ CSIRO Division of Plant Industry, Canberra, A.C.T. 260 I, Australia
}

(Received 3I October 1972; revised 6 March 1973)

\begin{abstract}
SUMMARY
Fractions containing particulate-bound ribosomes were prepared from Peronospora tabacina conidia during germination and shown to transfer amino acids from aminoacyl-tRNA into protein. Regardless of the stage during germination used to prepare $\left[{ }^{14} \mathrm{C}\right]$ aminoacyl-tRNA, the transfer activity of the fraction from germinated conidia was greater than that from freshly harvested conidia. Peptide-chain elongation factors also appear not to alter during germination. It is concluded that the activation of protein synthesis early in germination does not result from changes associated with the formation of aminoacyl-tRNA, or from changes in the peptide-chain elongation factors. Additional experiments revealed alterations in the attachment of these particulate-bound ribosomes during germination, and a scheme is proposed which relates these observations to the possible events occurring at the initiation of germination.
\end{abstract}

\section{INTRODUCTION}

Like the spores of several other fungi (Allen \& Dunkle, I97I) the conidia of Peronospora tabacina contain a germination inhibitor (Shepherd \& Mandryk, I962) which must be removed if germination is to occur. Removal can best be achieved by repeatedly washing conidia with distilled water at $0^{\circ} \mathrm{C}$ (this seems likely to keep all other metabolic activity to a minimum), and when subsequently incubated these washed conidia normally produce germ tubes after about $60 \mathrm{~min}$. It has already been shown that this process of germ-tube formation requires the synthesis of new proteins but apparently not the synthesis of new RNA (Hollomon, 1969). Although the nature of these proteins required for germination has yet to be established, their synthesis appears to be controlled at the translation level of protein synthesis, and is dependent on messenger RNA already present within ungerminated conidia.

Experiments with ${ }^{14} \mathrm{C}$-amino acids have shown that freshly harvested conidia are capable of only a limited amount of protein synthesis and that, once the germination inhibitor is removed and incubation begins, there is a considerable increase in the amount of protein synthesized (Hollomon, 1971). How this activation of protein synthesis is brought about was further investigated by using cell-free protein-synthesizing systems prepared from conidia at various stages throughout germination. The changes in activity of these cell-free systems during germination reflected closely the changes in protein-synthesizing activity already observed in intact conidia. Further characterization of the cell-free protein-synthesizing systems revealed that at least two systems were involved, and that much of the protein

* Present address: Long Ashton Research Station, Bristol, BSi 8 9AF.

Vol. 77, No. 2, was issued 27 August 1973 
required for germ-tube formation appeared to be synthesized on particulate-bound ribosomes which could be sedimented by centrifugation at $20000 \mathrm{~g}$ (Hollomon, 197I). This $20000 \mathrm{~g}$ particulate fraction has been examined further in the present study.

\section{METHODS}

Preparation of cell-free extracts. Conidia were collected and prepared as described previously (Hollomon, 1970) and when germinated conidia were required suspensions containing $2 \times 10^{5}$ conidia $/ \mathrm{ml}$ were used. Unless stated otherwise germinated conidia were incubated for $60 \mathrm{~min}$. Details of the methods used to prepare the $20000 \mathrm{~g}$ fractions are given elsewhere (Hollomon, I97I). Electron micrographs of the fractions showed many ribosomes associated with membrane fragments, but failed to reveal obvious differences between fractions prepared from both freshly harvested and germinated conidia. Each fraction was suspended in $0.33 \mathrm{ml} \mathrm{KMT}$ buffer (O.0I M-tris- $\mathrm{HCl}, \mathrm{pH} 7.4$; 0.0 I M-magnesium acetate; $0.06 \mathrm{M}-\mathrm{KCl} ; 0.006 \mathrm{M}$-2-mercaptoethanol) and assayed for transfer activity.

Preparation of $\left[{ }^{14} C\right]$ aminoacyl-tRNA. tRNA was extracted from high speed supernatants from both freshly harvested and germinated conidia by using the phenol: $1 \%$ sodium dodecylsulphate (SDS) procedure. Any attached amino acids were removed by incubation at $\mathrm{pH} 10.0$ for $30 \mathrm{~min}$. Aminoacyl-tRNA synthetases were prepared according to the method of Muench \& Berg (1966) in which chromatography on DEAE cellulose is used to remove tRNAs. tRNA was charged with ${ }^{14} \mathrm{C}$ amino acids essentially according to the method of Kaji, Kaji \& Novelli (I965). Germinated tRNA was charged using the enzyme fraction from germinated conidia; freshly harvested tRNA was charged using the 'freshly harvested' enzyme. $\left[{ }^{14} \mathrm{C}\right.$ ]aminoacyl-tRNA was purified by precipitation with $\mathrm{I} \%(\mathrm{w} / \mathrm{v})$ cetyl trimethylammonium bromide (CTAB). The CTAB-RNA salt was converted to Na-RNA by washing with $70 \%(\mathrm{v} / \mathrm{v})$ ethanol in $0 . \mathrm{I}$ M-sodium acetate and the [ $\left.{ }^{14} \mathrm{C}\right]$ aminoacyl-tRNA dissolved in $0.01 \mathrm{M}$-sodium acetate, $\mathrm{pH} 6.5$, and stored at $-15{ }^{\circ} \mathrm{C}$.

Assay of transfer activity. The reaction mixture contained (in a final volume $0.125 \mathrm{ml}$ ): I.2 $\mu$ mole tris, $\mathrm{pH} \mathrm{7.4;} \mathrm{I.2 \mu mole} \mathrm{magnesium} \mathrm{acetate;} 7.2 \mu$ moles $\mathrm{KCl} ; 0.72 \mu$ mole 2 mercaptoethanol; $0.08 \mu$ mole GTP; $3 \mu$ moles PEP (sodium salt); $0.05 \mu$ mole sodium acetate; $2.5 \mu \mathrm{g}$ pyruvate kinase; $5.0 \mu \mathrm{g}$ chloramphenicol; $330 \mu \mathrm{g} 20000 \mathrm{~g}$ fraction protein. The amount of $\left[{ }^{14} \mathrm{C}\right]$ aminoacyl-tRNA added is given in the relevant Figure or Table. The reaction mixture was incubated at $25{ }^{\circ} \mathrm{C}$ and incorporation stopped after $\mathrm{I} 5 \mathrm{~min}$ by addition of $5 \%(\mathrm{w} / \mathrm{v})$ trichloroacetic acid (TCA) + $0 . \mathrm{I} \%(\mathrm{w} / \mathrm{v})$ Casamino acids and I $\mathrm{mg}$ bovineserum albumin. Samples were then treated as described previously (Hollomon, I97I) before the radioactivity was counted, with an efficiency of $60 \%$, in a Packard Tri-Carb spectrometer with 2-5-diphenoxazole (6.0 g/l toluene) as a scintillant.

Preparation of peptide-chain elongation factors. Fractions $(20000 \mathrm{~g})$ prepared from both freshly harvested and germinated conidia were washed with buffer containing 0.01 M-tris$\mathrm{HCl}, \mathrm{pH} 7.4 ; 0.0 \mathrm{I}$ M-magnesium acetate; $\mathrm{M}-\mathrm{KCl} ; 0.006 \mathrm{M}-2$-mercaptoethanol; I \% (v/v) Triton X-IOo. Sufficient saturated $\left(\mathrm{NH}_{4}\right)_{2} \mathrm{SO}_{4}$ solution, neutralized by the addition of $5 \mathrm{mg}$

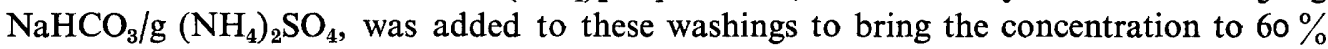
saturated $\left(\mathrm{NH}_{4}\right)_{2} \mathrm{SO}_{4}$. The insoluble material was collected by centrifugation, dissolved in $\mathrm{I} \cdot \mathrm{O} \mathrm{ml}$ KMT buffer, and dialysed against the same buffer. All preparations were stored frozen at $-15{ }^{\circ} \mathrm{C}$ and used within one week, during which time about $10 \%$ of the initial activity was lost.

Analysis of ribosomal RNA ( $r R N A)$. Particulate fractions $(20000 \mathrm{~g})$ were resuspended in SDS buffer [5\%(w/v) SDS (B.D.H. specially pure); 0.05 M-tris- $\mathrm{HCl}, \mathrm{pH} \mathrm{8.0;0.05} \mathrm{M-ethylene}$ 
diamine tetra acetic acid, disodium salt (EDTA)] by gentle stirring at $25^{\circ} \mathrm{C}$ for $15 \mathrm{~min}$. Insoluble material was removed by centrifugation at $10000 \mathrm{~g}$ for $\mathrm{I} 0 \mathrm{~min}$, and the RNA in the supernatant solution fractionated directly by polyacrylamide gel electrophoresis, after the addition of sufficient glycerol to the supernatant to provide a final concentration of $10 \%$ $(\mathrm{v} / \mathrm{v})$ glycerol. Polyacrylamide gels were prepared according to the method of Loening (1967), except that $\mathrm{I} \%(\mathrm{w} / \mathrm{v})$ agarose was added. Samples were layered directly onto the gels and electrophoresis was carried out for $210 \mathrm{~min}$ at $5 \mathrm{~mA} / \mathrm{gel}$ and $7 \mathrm{~V} / \mathrm{cm}$ using tris + acetate buffer (0.045 M-tris; $0.02 \mathrm{M}$-Na acetate; 2 mM-sodium EDTA; acetic acid was used to adjust to $\mathrm{pH} 7.3$ at $25^{\circ} \mathrm{C}$ ). After electrophoresis gels were rinsed in distilled water for $30 \mathrm{~min}$ and scanned by using transmitted u.v. irradiation by the method of Loening (I969) (except that the $p$-dimethylaminobenzaldehyde filter was omitted).

$\left[{ }^{3} \mathrm{H}\right]$ Neurospora crassa RNA added with the SDS buffer was recovered unaltered indicating that RNAase was not active during extraction and electrophoresis. However, some degradation possibly occurred during the preparation of the $20000 \mathrm{~g}$ fraction before treatment with SDS, although $\left[{ }^{3} \mathrm{H}\right] N$. crassa RNA added to conidial homogenates remained substantially undegraded. Co-electrophoresis with cytoplasmic ribosomal RNAs (rRNAs) from $N$. crassa indicated that Peronospora tabacina rRNAs were of a similar size (28S and I $8 \mathrm{~S}$ ) and that the particulate fractions contained little, if any, mitochondrial RNA. SDS treatment of the $20000 \mathrm{~g}$ fraction appeared to solubilize all the RNA present; additional RNA was not removed by a second extraction with SDS and RNA could not be detected by the method of Munro \& Fleck (I966) in the residue remaining after SDS treatment.

Other determinations. Protein was determined by the method of Lowry, Rosebrough, Farr \& Randall (I95I) with bovine-serum albumin as the standard. RNA was measured spectrophotometrically as $\mathrm{Mg}$-RNA assuming that I $\mathrm{mg}$ of $\mathrm{Mg}-\mathrm{RNA} / \mathrm{ml}$ was equivalent to 20 absorbance units at $260 \mathrm{~nm}$.

Radioisotope. ${ }^{14} \mathrm{C}$ amino acid mixture, CFB. I04, was purchased from The Radiochemical Centre, Amersham, Buckinghamshire and contained a mixture of 14 l-amino acids with spec. act. $52 \mathrm{mCi} / \mathrm{m}$ Atom carbon.

\section{RESULTS}

Transfer activity. Characterisation of the incorporation of amino acids from aminoacyltRNAs into polypeptide by the $20000 \mathrm{~g}$ fractions from germinated and freshly harvested Peronospora tabacina conidia are given in Table $\mathrm{I}$. Incorporation was inhibited by RNAase and inhibitors (anisomycin, cycloheximide, fusidic acid, sparsomycin) which block peptide chain elongation (Pestka, 1971). Incorporation, which was linear for $15 \mathrm{~min}$, was sensitive to changes in the magnesium concentration. At $\mathbf{2 \cdot 2} \mathrm{mM}$-magnesium, incorporation decreased by $95 \%$, at 36 mM-magnesium, incorporation was reduced by $85 \%$. Although only partially dependent on GTP, the presence of a GTP-generating system (PEP and pyruvate kinase; Strominger, 1955) appeared essential. If the $\left[{ }^{14} \mathrm{C}\right]$ aminoacyl-tRNAs were incubated at $\mathrm{pH} 10.0$ for $30 \mathrm{~min}$ at $37{ }^{\circ} \mathrm{C}$, and subsequently neutralized, the resulting mixture of ${ }^{14} \mathrm{C}$ amino acids and uncharged tRNAs no longer supported the transfer of amino acids into protein. This indicates that under these assay conditions where ATP is absent, attachment of amino acids to tRNA did not take place.

Figure I $a$ shows the effect of increasing amounts of $\left[{ }^{14} \mathrm{C}\right]$ aminoacyl-tRNA (prepared from germinated conidia) on the transfer reaction of both germinated and freshly harvested $20000 \mathrm{~g}$ fractions. Although not completely saturated with aminoacyl-tRNA, the transfer activity of the $20000 \mathrm{~g}$ fraction from germinated conidia was 3 to 4 times greater than that from freshly harvested conidia. Similar results were obtained by using $\left[{ }^{14} \mathrm{C}\right]$ aminoacyl-tRNA 
Table I. Characteristics of polypeptide synthesis by $20000 \mathrm{~g}$ fractions prepared from freshly harvested and germinated Peronospora tabacina conidia*

\section{C.p.m. incorporated $/ \mathrm{mg}$ total} protein in conidial extract $\uparrow$

\section{Additions or omissions $\ddagger$}

Complete system

- GTP

-GTP, PEP, pyruvate kinase

+ Cycloheximide $(28 \mu \mathrm{g})$

+ Anisomycin $(33 \mu \mathrm{g})$

+ Fusidic acid $(640 \mu \mathrm{g})$

+ Sparsomycin $(2 \cdot 5 \mu \mathrm{g})$

+ RNAase $(\mathrm{I} \cdot \% \mathrm{~g})$

+ DNAase $(10 \circ \mu \mathrm{g})$

+ Actinomycin $\mathrm{D}(8 \cdot 0 \mu \mathrm{g})$

Complete system but ${ }^{19} \mathrm{C}$ amino acids plus tRNA instead of $\left[{ }^{14} \mathrm{C}\right]$ aminoacyltRNA

\begin{tabular}{|c|c|}
\hline $\begin{array}{c}\text { Freshly } \\
\text { harvested } \\
20000 \mathrm{~g} \\
\text { fraction }\end{array}$ & $\begin{array}{l}\text { Germinated } \\
20000 \mathrm{~g} \\
\text { fraction }\end{array}$ \\
\hline $\begin{array}{l}150 \\
116\end{array}$ & $\begin{array}{l}586 \\
469\end{array}$ \\
\hline 15 & 58 \\
\hline 15 & 129 \\
\hline 3 & I8 \\
\hline 0 & 0 \\
\hline 0 & 0 \\
\hline 0 & 29 \\
\hline I56 & 510 \\
\hline 138 & 435 \\
\hline 0 & 0 \\
\hline
\end{tabular}

* Both fractions were prepared and assayed for transfer activity as described in Methods.

$\dagger$ In these experiments no more than $70 \%$ of the conidia were disrupted by homogenization; further homogenization increased breakage without increasing incorporation. To correct for any differences in the number of broken conidia, and to permit a comparison between experiments, results are expressed in terms of the total protein content of the conidial extract, after any unbroken conidia were removed by centrifugation at $1000 \mathrm{~g}$ for $\mathrm{I} \mathrm{min}$. See also Hollomon (1971).

$\ddagger\left[{ }^{14} \mathrm{C}\right]$ aminoacyl-tRNA (spec. act. 71200 c.p.m. $/ \mathrm{mg}$ tRNA) containing 4500 c.p.m. and prepared from freshly harvested conidia, was added. In the complete system, the $20000 \mathrm{~g}$ fraction from germinated conidia incorporated 2642 c.p.m. into protein.

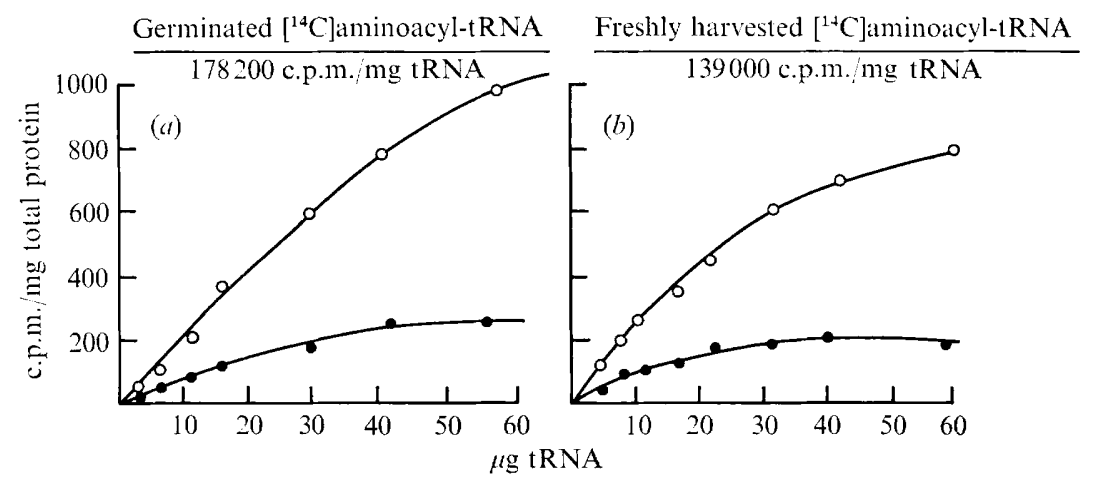

Fig. I. Effect of increasing amounts of $\left[{ }^{14} \mathrm{C}\right]$ aminoacyl-tRNA on polypeptide synthesis by $20000 \mathrm{~g}$ fractions prepared from germinated $\left(O_{-}\right)$) and freshly harvested conidia (O-O). (a) [ $\left.{ }^{14} \mathrm{C}\right]$ aminoacyl tRNA prepared from germinated conidia; $(b)\left[{ }^{14} \mathrm{C}\right]$ aminoacyl-tRNA prepared from freshly harvested conidia.

prepared from freshly harvested conidia (Fig. I $b$ ). Thus, regardless of the stage during germination used to prepare $\left[{ }^{4} \mathrm{C}\right]$ aminoacyl-tRNA, the germinated $20000 \mathrm{~g}$ fraction was always more active than that from the freshly harvested conidia. In additional experiments not reported here, $20000 \mathrm{~g}$ fractions prepared from conidia at intermediate stages during 


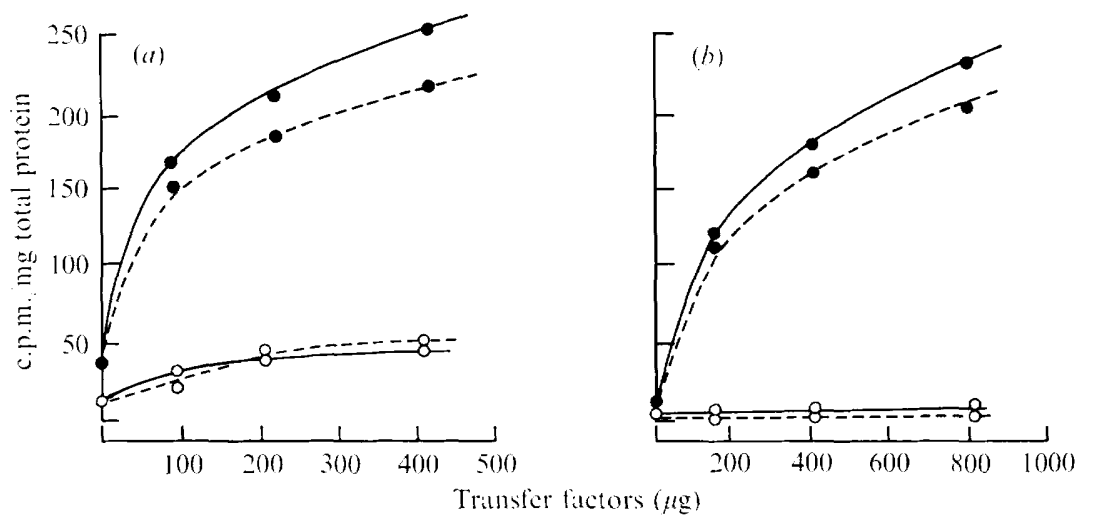

Fig. 2. Restoration of polypeptide synthesis by the addition of peptide-chain elongation factors to $20000 \mathrm{~g}$ fractions previously washed with $(a) \mathrm{M}-\mathrm{KCl}$ alone; $(b) \mathrm{M}-\mathrm{KCl}$ plus $\mathrm{I} \%$ Triton X-Ioo. Peptide-chain elongation factors were obtained from either germinated ( - ) or freshly harvested (-- - - $)$ conidia according to the procedure described in Methods. These were added back to washed $20000 \mathrm{~g}$ fractions prepared from both germinated $(O)$ and freshly harvested conidia (O). In both experiments $\left[{ }^{14} \mathrm{C}\right]$ aminoacyl-tRNA was prepared from freshly harvested conidia; in (a) 4900 c.p.m. [ $\left.{ }^{14} \mathrm{C}\right]$ aminoacyl-tRNA (spec. act. 178000 c.p.m./mg tRNA), were added to each assay tube, in (b) 3438 c.p.m. [ ${ }^{14} \mathrm{C}$ ] aminoacyl-tRNA (spec. act. 172000 c.p.m./mg tRNA) were used in each assay.

germination were assayed for transfer activity by using $\left[{ }^{14} \mathrm{C}\right]$ aminoacyl-tRNA prepared from freshly harvested conidia. Activity increased slightly during washing at $0{ }^{\circ} \mathrm{C}$, but then increased rapidly once incubation at $15{ }^{\circ} \mathrm{C}$ had begun. These changes in the transfer activity of this fraction during germination resemble closely those already reported for amino-acid incorporating activity (Hollomon, 1971). It appears, therefore, that the activation of protein synthesis early in germination resulted not from changes affecting the formation of aminoacyl-tRNAs but from alterations at some subsequent step in protein biosynthesis.

\section{The activity of peptide-chain elongation factors during germination}

In some fungal systems repeated washing is sufficient to deplete ribosomes of certain additional proteins that are essential for peptide-chain elongation (Heredia \& Halvorson, 1966). More frequently complete removal of these elongation factors requires treatment with either detergents or solutions of high ionic strength. The transfer activity of the $20000 \mathrm{~g}$ fractions from both germinated and freshly harvested Peronospora tabacina conidia was decreased by repeated washings with $\mathrm{KMT}$ buffer containing either $\mathrm{M}-\mathrm{KCl}$ alone or, more effectively, $\mathrm{M}-\mathrm{KCl}$ plus I \% (v/v) Triton X-Ioo. This activity could largely be restored to germinated residues by adding back peptide-chain elongation-factor preparations (see Methods) from either $\mathrm{M}-\mathrm{KCl}$ washings (Fig. $2 a$ ) or $\mathrm{M}-\mathrm{KCl}$ plus I $\%$ Triton X-I00 washings (Fig. 2b). Anisomycin, cycloheximide, fusidic acid, sparsomycin and RNAase all inhibited this restored activity, and in the absence of any washed $20000 \mathrm{~g}$ fraction, the factor preparations themselves showed no transfer activity. Activity could also be restored to freshly harvested $20000 \mathrm{~g}$ residues obtained by washing with $\mathrm{M}-\mathrm{KCl}$ alone (Fig. 2a), but not to freshly harvested residues prepared by washing with $\mathrm{M}-\mathrm{KCl}$ plus I $\%$ Triton X-roo (Fig. $2 b$ ). In all of these experiments the elongation-factor preparations from both freshly harvested and germinated conidia were interchangeable, suggesting that the activation of protein 
synthesis early in germination results from changes associated, not with these elongation factors, but with some component of the protein synthesizing system remaining in the 20000 $g$ residue.

\section{Ribosome attachment to the $20000 \mathrm{~g}$ fraction}

In many systems detergent treatment is known to detach at least some particulate-bound ribosomes. Consequently, it was decided to examine the nature of the attachment of these particulate-bound ribosomes at various stages during germination, and how binding might be affected by treatment with $\mathrm{M}-\mathrm{KCl}$ plus $\mathrm{I} \%$ Triton X-Ioo.

The ribosomes present in each $20000 \mathrm{~g}$ fraction were examined by analysis of their rRNA (28S and I $8 \mathrm{~S}$ ) components (see Methods). Fig. 3 (A) shows the relative amounts of $28 \mathrm{~S}$ and I $8 \mathrm{~S}$ rRNA in the $20000 \mathrm{~g}$ fraction at four stages during germination. Removal of the germination inhibitor led to the loss of $18 \mathrm{~S}$ rRNA, indicating that small ribosomal subunits were detached from the particulate fraction during washing. This loss of I8S rRNA was more pronounced if, as other evidence suggests, the two unidentified bands migrating faster than rRNA were derived from I8S rRNA. These two bands were lost completely from the $20000 \mathrm{~g}$ fraction when conidia were washed. After incubation at $15^{\circ} \mathrm{C}$ had begun, the relative amount of I8S rRNA increased indicating reattachment of the small ribosomal subunit to the $20000 \mathrm{~g}$ fraction. If conidia were washed in the presence of cycloheximide, but subsequently incubated in the absence of this protein-synthesis inhibitor, germination nevertheless proceeded quite normally (unpublished results). By contrast, conidia incubated in the presence of cycloheximide failed to germinate regardless of whether or not cycloheximide was present when conidia were washed. As in the control, I8S rRNA was lost from the $20000 \mathrm{~g}$ fraction during the washing of conidia in the presence of cycloheximide (Fig. 3 B). However, if cycloheximide were present, reattachment of the small ribosomal subunit during incubation no longer took place. Cycloheximide not only inhibits peptidechain elongation (Pestka, I97I) but also prevents the initiation of protein synthesis (Obrig, Culp, McKeehan \& Hardesty, I97I) and this may account for the failure of the small ribosomal subunits to reattach to the $20000 \mathrm{~g}$ fraction. The loss of only small ribosomal subunits strongly suggests that these particulate-bound ribosomes were attached by their large subunits. Since cycloheximide totally inhibits protein synthesis (Hollomon, I97I) these large ribosomal subunits could not have been anchored by the nascent polypeptide chains.

$\beta$-Ionone prevents the germination of Peronospora tabacina conidia but does not impair viability (Leppik, Hollomon \& Bottomley, 1972). As with cycloheximide, I8S rRNA was lost from the $20000 \mathrm{~g}$ fraction of conidia washed in the presence of $\beta$-ionone, and reattachment of small ribosomal subunits did not take place during incubation in its presence (Fig. 3 C). Reattachment did occur during incubation in the presence of ethidium bromide (Fig. 3D), which inhibits RNA synthesis in P. tabacina but not germination (Hollomon, I 969 ; I970). As expected, I8 S rRNA was also lost from the $20000 \mathrm{~g}$ fraction of conidia washed in the presence of ethidium bromide, but the two unidentified bands which migrated faster than rRNA were not detected, and it is suggested that ethidium bromide in some way prevented their formation from I8S rRNA.

\section{Effect of detergent on ribosome binding}

In freshly harvested conidia all ribosomes were readily detached from the $20000 \mathrm{~g}$ fraction by treatment with $\mathrm{M}-\mathrm{KCl}$ plus $\mathrm{I} \%$ Triton X-I00 (Fig. 4A). After the conidia were washed at $0{ }^{\circ} \mathrm{C}$, some $28 \mathrm{~S}$ and I8S rRNA remained associated with this fraction but, once 

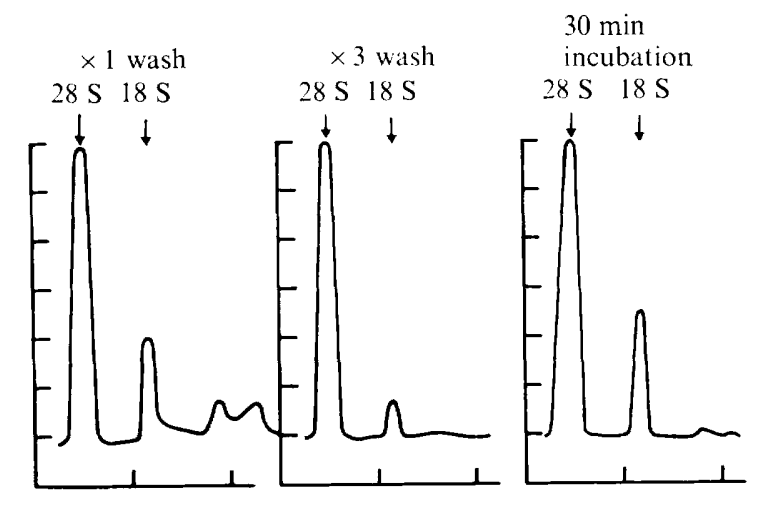

$60 \mathrm{~min}$

incubation

$28 \mathrm{~S} 18 \mathrm{~S}$
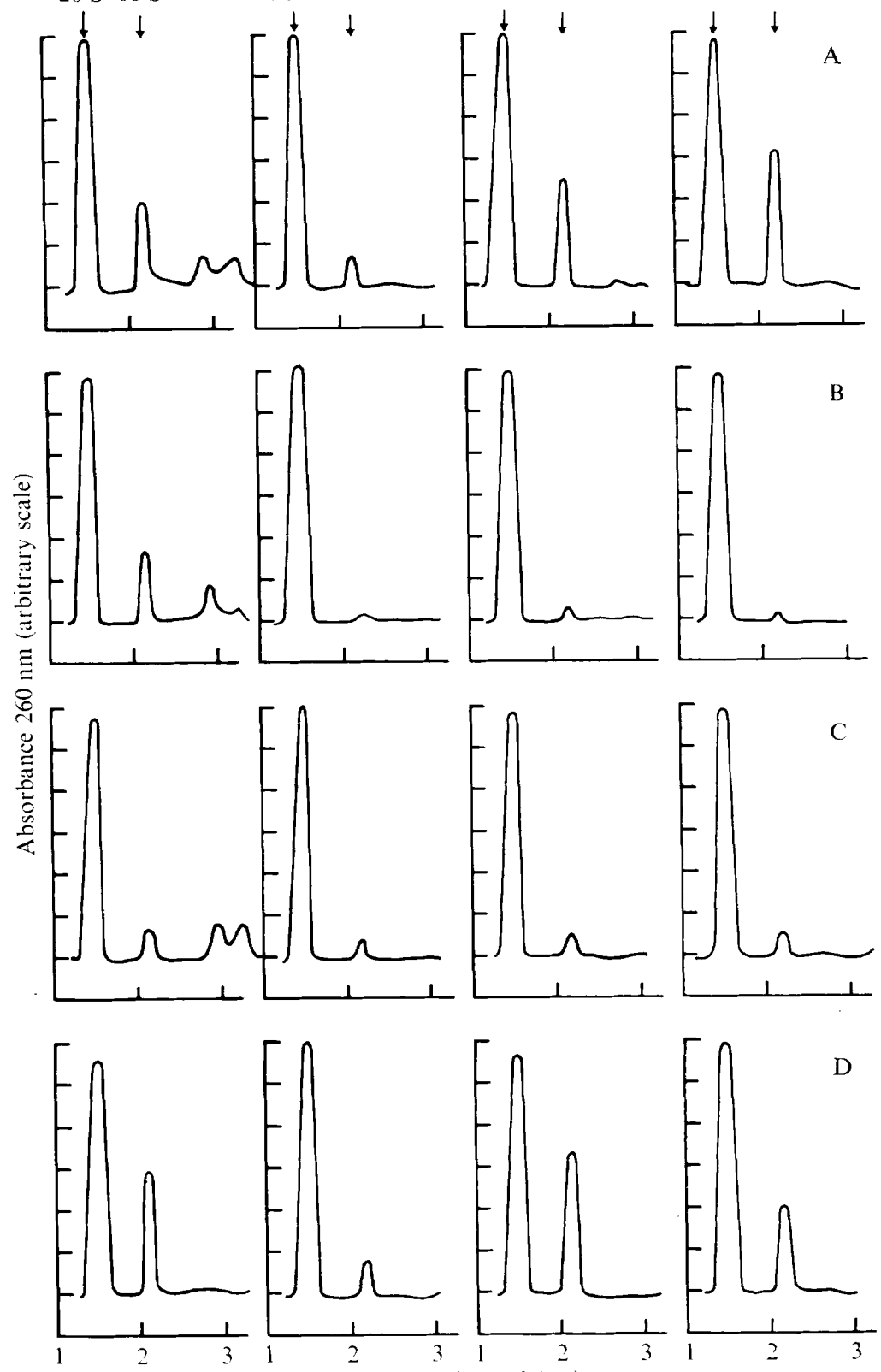

Distance migrated $(\mathrm{cm})$

Fig. 3. Particle-bound ribosomal RNA from conidia at several stages during germination: Effect of cycloheximide, $\beta$-ionone, and ethidium bromide. Conidia were collected, washed three times with distilled water (containing chloramphenicol $100 \mu \mathrm{g} / \mathrm{ml}$ ) at $0^{\circ} \mathrm{C}$, and incubated as described previously (Hollomon, 197I). In the experiments using cycloheximide (I.I2 $\mu \mathrm{g} / \mathrm{ml}), \beta$-ionone (I $\mu \mathrm{g} / \mathrm{ml})$ and ethidium bromide $(50 \mu \mathrm{g} / \mathrm{ml})$, each compound was present during collection, washing, and incubation of conidia. Details of the methods used to prepare the $20000 \mathrm{~g}$ particulate fraction, which contains particle-bound ribosomes, are given elsewhere (Hollomon, 1971). Samples, containing $80 \mu \mathrm{g}$ protein (for the freshly harvested treatment in the control series approx. $50 \mu \mathrm{g}$ RNA) were layered directly onto the polyacrylamide gels and electrophoresis was carried out as described in Methods. Only that region of the trace showing rRNAs is shown. (A) Control;(B) cycloheximide; (C) $\beta$-ionone; (D) ethidium bromide. 


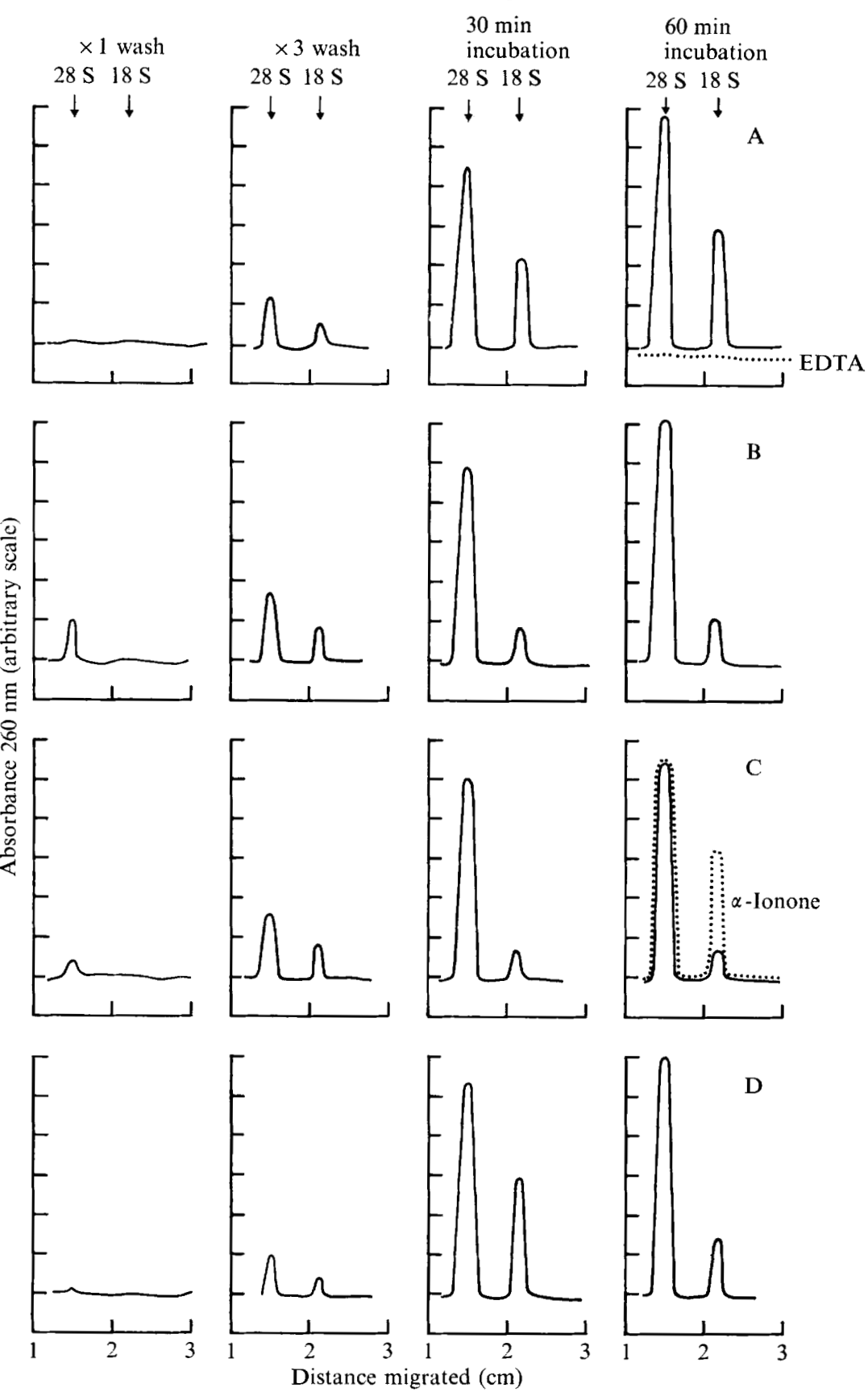

Fig 4. For legend see facing page.

incubation of conidia at $15{ }^{\circ} \mathrm{C}$ began, detachment of both rRNA components from the $20000 \mathrm{~g}$ fraction became increasingly resistant to treatment with $\mathrm{M}-\mathrm{KCl}$ plus $\mathrm{I} \%$ Triton $X-100$. The ratio of $28 \mathrm{~S}$ rRNA: $18 \mathrm{~S}$ rRNA remaining attached to the membrane fraction was close to $2: \mathrm{I}$, suggesting that completed ribosomes were present. These ribosomes were probably actively synthesizing protein since, in the presence of $\mathrm{M}-\mathrm{KCl}$, ribosomes not 
engaged in protein synthesis might be expected to dissociate into subunits (Martin \& Wool, 1969; Falvey \& Staehelin, 1970). Small subunits produced in this way would be lost if, as present evidence suggests, ribosomes are attached to the $20000 \mathrm{~g}$ fraction by the large ribosomal subunits only. Further treatment of the detergent-washed $20000 \mathrm{~g}$ fraction with as little as I.0 mM-EDTA completely detached both $28 \mathrm{~S}$ and I $8 \mathrm{~S}$ rRNA (Fig. $4 \mathrm{~A}, 60 \mathrm{~min}$ of incubation). Despite the failure of conidia washed and incubated in the presence of cycloheximide to germinate, association of the $28 \mathrm{~S}$ rRNA with the $20000 \mathrm{~g}$ fraction after treatment with $\mathrm{M}-\mathrm{KCl}$ plus $\mathrm{I} \%$ Triton $\mathrm{X}-\mathrm{I} 00$ nevertheless followed the pattern already established for germinating conidia (Fig. 4B), whereas hardly any I8S rRNA remained associated with this fraction. Substantially similar changes in the attachment of $28 \mathrm{~S}$ rRNA to the $20000 \mathrm{~g}$ fraction without the corresponding attachment of I $8 \mathrm{~S}$ rRNA, were seen in conidia washed and incubated in the presence of $\beta$-ionone (Fig. ${ }_{4} \mathrm{C}$ ). By contrast, after 60 min of incubation in the presence of $\alpha$-ionone, which is without effect on germination (Leppik et al. 1972), both rRNA components remained attached to the $20000 \mathrm{~g}$ fraction after treatment with $\mathrm{M}-\mathrm{KCl}$ plus $\mathrm{I} \%$ Triton X-I00 (Fig. 4C, $60 \mathrm{~min}$ of incubation). The addition of $\beta$-ionone to the buffers used in the preparation and treatment of these fractions from germinating conidia had no apparent effect on the attachment of the $28 \mathrm{~S}$ and I8S rRNA. Thus, $\beta$-ionone was effective only when present in vivo and had no direct effect on the retention of the small subunit on the $20000 \mathrm{~g}$ fraction after treatment with $\mathrm{M}-\mathrm{KCl}$ plus $\mathrm{I} \%$ Triton X-I00. Treatment of this fraction from conidia washed and incubated in the presence of ethidium bromide produced somewhat similar results to those obtained with control conidia (Fig. 4D).

\section{DISCUSSION}

New tRNA synthesis is not essential for germination (Hollomon $1969 ; 1970$ ) but modification of existing molecules early in germination, together with alteration to the aminoacyltRNA synthetases, might significantly enhance their acceptor activity and, in this way, account for the activation of protein synthesis. Changes in at least some of these aminoacyltRNA synthetases occur during fungal spore germination (Van Etten \& Brambl, I968; Schmoyer \& Lovett, I969), but no conclusive evidence yet exists to indicate that these changes play a critical role in the control of germination.

The experiments described here examine the transfer reaction of particulate-bound

Fig. 4. Particle-bound ribosomal RNA; effect of treatment with $\mathrm{M}-\mathrm{KCl}$ plus $\mathrm{I} \%$ Triton X-100. A $20000 \mathrm{~g}$ particulate fraction was prepared from conidia as described in Fig. 3. This fraction was resuspended in $2.0 \mathrm{ml}$ buffer (0.0 I M-tris- $\mathrm{HCl}, \mathrm{pH} \mathrm{7.4;0.01} \mathrm{M-magnesium} \mathrm{acetate;} \mathrm{M}-\mathrm{KCl} ; 0.006$ M-2-mercaptoethanol; I \% Triton X-100) and any soluble material discarded after centrifugation at $20000 \mathrm{~g}$ for $20 \mathrm{~min}$. This process was repeated and the pellet washed again in $2.0 \mathrm{ml}$ buffer (0.01 M-tris- $\mathrm{HCl}, \mathrm{pH} \mathrm{7.4;} \mathrm{0.0} \mathrm{I} \mathrm{M-magnesium} \mathrm{acetate;} 0.06 \mathrm{M}-\mathrm{KCl}$; $0.006 \mathrm{M}-2$-mercaptoethanol; $0.25 \mathrm{M}$ sucrose). This was found to be essential if precipitation of potassium dodecyl sulphate was to be avoided. The final pellet was resuspended in SDS buffer and any insoluble material removed by centrifugation at $10000 \mathrm{~g}$ for $10 \mathrm{~min}$ before the RNA was fractionated by polyacrylamide gel electrophoresis. Samples containing $50 \mu \mathrm{g}$ protein (for $60 \mathrm{~min}$ of incubation in control series approx. $50 \mu \mathrm{g}$ RNA) were layered into each gel. Where treatment with EDTA was employed (6o min incubation control series, dotted line) the pellet remaining after washing with $\mathrm{M}-\mathrm{KCl}$ plus $\mathrm{I} \%$ Triton $\mathrm{X}$ - $\mathrm{I} 00$ was suspended in $2.0 \mathrm{ml}$ buffer $(0.0 \mathrm{I} \mathrm{M}-\mathrm{tris}-\mathrm{HCl}, \mathrm{pH} 7.4 ; 0.06 \mathrm{M}-\mathrm{KCl} ; 0.006 \mathrm{M}-2$-mercaptoethanol; $0.001 \mathrm{M}-E D T A)$ stirred for $15 \mathrm{~min}$ at $0^{\circ} \mathrm{C}$, and finally centrifuged for $20 \mathrm{~min}$ at $20000 \mathrm{~g}$. The supernatant was discarded and the pellet resuspended in SDS buffer, and applied to the gel as before. Cycloheximide, $\beta$-ionone, and ethidium bromide were also used as described in Fig. 3. (A) Control; (B) cycloheximide; (C) $\beta$-ionone ( $\alpha$-ionone was used at a concentration of $1 \mu \mathrm{g} / \mathrm{ml}$, dotted line); (D) ethidium bromide. 
ribosomes and not free ribosomes as is more usual. Nevertheless, the characteristics of the reaction appear identical to those already reported for free ribosomes (Allende, 1967). While not eliminating the possibility that there may be changes during germination in the tRNAs and aminoacyl-tRNA synthetases, protein synthesis is clearly not limited at any stage by a lack of these components. Thus changes in either tRNAs or aminoacyl-tRNA synthetases seem unlikely to be involved in the activation of protein synthesis which probably involves changes at some step in protein biosynthesis subsequent to the aminoacylation of tRNA. This assumes that the aminoacyl-tRNAs prepared from components of the soluble cell fraction, and the aminoacyl-tRNAs formed by components of the $20000 \mathrm{~g}$ fraction itself, are in equilibrium and can be interchanged. Certainly amino acids are readily transferred from aminoacyl-tRNA prepared from soluble components into protein by the $20000 \mathrm{~g}$ fraction, arguing in favour of this assumption. Indeed, some recent work (Bandyopadhyay \& Deutcher, 197I ; Roberts \& Coleman, 1972) suggests that the presence of both tRNA and aminoacyl-tRNA synthetases in the soluble fraction may be the consequence of cell disruption, and that normally these components exist within the cell as a complex, perhaps associated with the other components of the protein-synthesizing system.

As well as a peptide bond-forming enzyme (peptidyltransferase), which appears to be an integral part of the large ribosomal subunit, two additional protein factors have so far been implicated in the process of peptide-chain elongation in eukaryotic organisms (LucasLenard \& Lipmann, 1971). Yet other protein factors are required for the initiation (Prichard, Gilbert, Shafritz \& Anderson, I970; Heywood \& Thompson, 197I) and termination (Goldstein \& Caskey, 1970; Beaudet \& Caskey, 1971) of peptide synthesis. Changes in any of these factors might account for the activation of protein synthesis early in germination.

The purification of aminoacyl transferase I from Uromyces phaseoli by Yaniv \& Staples (197I) demonstrates the presence of one peptide-chain elongation factor in ungerminated uredospores. Earlier work (Yaniv \& Staples, I969) suggests that aminoacyl transferase II is also present and that the activity of both factors is unaltered before germ-tube emergence. No attempt was made in the experiments reported here to purify the elongation factors beyond precipitation with $\left(\mathrm{NH}_{4}\right)_{2} \mathrm{SO}_{4}$; however, little difference in activity could be found between factor preparations, suggesting that freshly harvested Peronospora tabacina conidia also contain the necessary elongation factors and that control of protein synthesis is accomplished by some other mechanism. Instead it was the residues remaining after treatment of the $20000 \mathrm{~g}$ fractions with either $\mathrm{M}-\mathrm{KCl}$, or $\mathrm{M}-\mathrm{KCl}$ plus $\mathrm{I} \%$ Triton $\mathrm{X}-\mathrm{I} 00$, that differed during germination in their capacity to support protein synthesis in the presence of added elongation factors. All attempts to solubilize the components responsible for this difference have so far been unsuccessful.

Germ-tube formation requires the synthesis of new proteins which appear to be synthesized primarily by particulate-bound ribosomes. Although ribosomes are present in the $20000 \mathrm{~g}$ fraction of freshly harvested conidia, these ribosomes seem unlikely to be engaged in protein synthesis since they readily dissociate in the presence of $\mathrm{M}-\mathrm{KCl}$ leading to the loss of the small ribosomal subunit from this fraction (unpublished results). It is proposed that reprogramming of these ribosomes with fresh messenger RNA can occur only after their dissociation into two subunits, and the formation of an initiation complex between the small ribosomal subunits and the messenger RNA which has been stored elsewhere in the conidium. This dissociation appears to take place when freshly harvested conidia are washed to remove the germination inhibitor. The large ribosomal subunits not only remain particlebound, but their attachment undergoes an alteration such that they are no longer removed by $\mathrm{KCl}$-detergent treatment. When attached in this way each large subunit appears ready to 


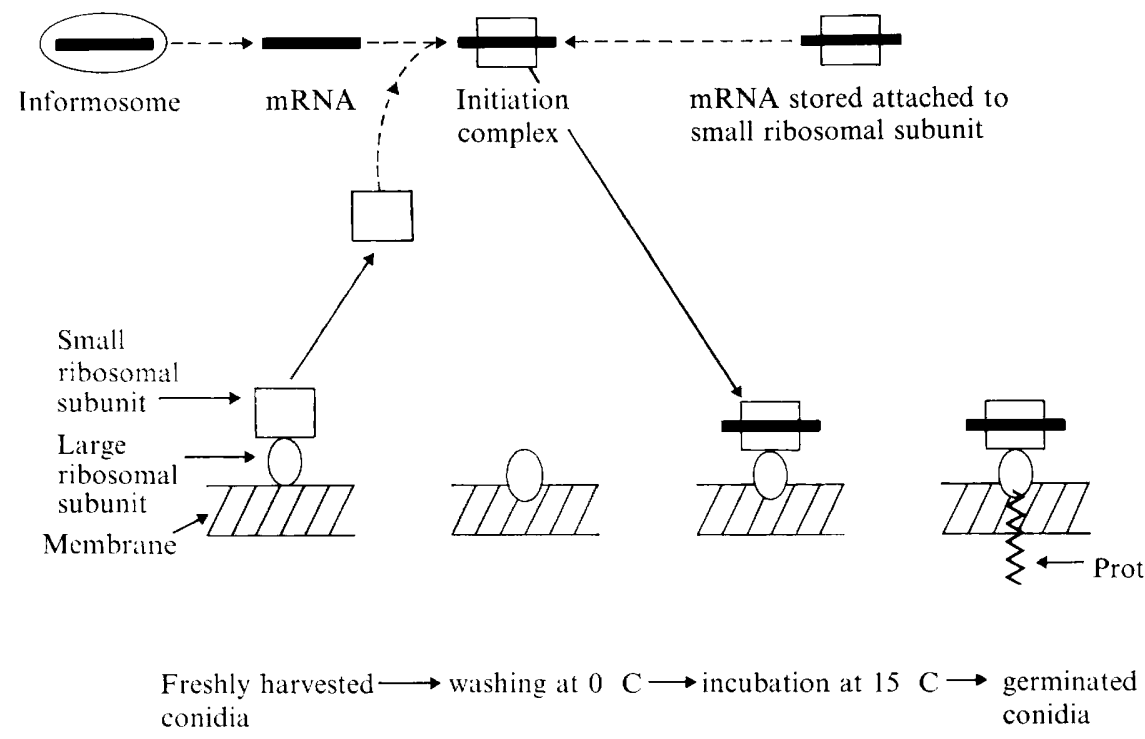

Fig. 5. Diagrammatic representation of the proposed changes in membrane-bound ribosomes during germination.

accept the small subunit-messenger RNA initiation complex. As new ribosomes are apparently not synthesized during germination (Hollomon, 1970), the small subunits involved in these initiation complexes must have either been present elsewhere in the cytoplasm of freshly harvested conidia, or are those subunits released when dissociation of the ribosomes takes place during the washing of the conidia. Once incubation of the conidia begins, formation of these re-programmed ribosomes, which no longer dissociate in the presence of $\mathrm{M}-\mathrm{KCl}$, increases together with the increasing synthesis of the proteins necessary for germtube formation.

Fig. 5 illustrates the changes in the attachment of ribosomal subunits which may occur during germination. In this scheme the ribosomes are depicted as being membrane-bound, although the exact nature of the material to which the ribosomes are attached is not yet clear. From this it is apparent that several points exist at which protein synthesis, and hence germination, could be controlled. Dissociation of the ribosomes during washing of the conidia, the loss of the small subunits from the membrane fraction, and the altered attachment of the remaining large subunit, all offer points at which germination could be controlled. However, while changes such as these may be essential if germination is to occur, they do not inevitably lead to the appearance of a germ tube. Instead, these early changes in the attachment of ribosomal subunits to the membrane probably result from the hydration of the conidia, and occur regardless of whether germination will eventually take place.

Protein synthesis necessary for germ-tube formation is apparently directed by messenger RNA present in freshly harvested conidia in a 'masked' form. Protection of this messenger RNA against the action of nucleases may be achieved by storage as a complex with protein (informosome; Spirin, 1969), although the existence of such particles has yet to be demonstrated in fungi. If stored in this way the attachment of the messenger RNA to the small ribosomal subunit to form an initiation complex, provides a further point at which the translation control of protein synthesis might be exerted. Alternatively, the masked messenger RNA could be stored and transported attached to the small ribosomal subunit. Despite 
earlier suggestions of such a mechanism (Joklik \& Becker, I965), the involvement of ribonucleoprotein particles of this nature in the storage of messenger RNA in eukaryotic cells has yet to be confirmed. Once formed the initiation complex must in some way recognize the large subunit already attached to the membrane. Baglioni, Bleiberg \& Zauderer (I97I) have suggested that, at least in mouse myeloma cells, specific initiation factors exist which recognize both a class of messenger RNA and the membrane-bound large ribosomal subunit. Several classes of ribosomes may well exist, each with a somewhat different protein composition, thus providing a basis for recognition. Attachment of the initiation complex to the large ribosomal subunit may, therefore, provide yet another point at which protein synthesis and germination could be controlled.

$\beta$-Ionone and its more active isobutyroxy ester, 5 -isobutyroxy- $\beta$-ionone, specifically inhibit the germination of Peronospora tabacina conidia (Leppik et al. 1972), without in any way impairing viability. 5 -Isobutyroxy- $\beta$-ionone was isolated from tobacco plants infected with $P$. tabacina but freshly harvested conidia contain compounds with similar biological and chemical properties. It is possible, therefore, that 5 -isobutyroxy- $\beta$-ionone is of fungal origin and that it is perhaps involved in the control of germination. As the experiments reported here show, $\beta$-ionone prevents the reattachment of the small ribosomal subunit to the membrane fraction. 5 -Isobutyroxy- $\beta$-ionone may control germination by preventing the attachment of the initiation complex to the membrane-bound large ribosomal subunit.

This work was supported by a grant from the Australian Tobacco Research Council. My thanks are due to Miss J. Flanigan for her skilful technical assistance and help in the preparation of this manuscript.

\section{REFERENCES}

Allen, P. J. \& Dunkle, L. D. (1971). Natural activators and inhibitors of spore germination. In Morphological and Biochemical Events in Plant-Parasite Interaction, pp. 23-58. Edited by S. Akai and S. Ouchi. Tokyo: Japanese Phytopathological Society.

Allende, J. E. (1967). Protein biosynthesis in plant systems. In Techniques in Protein Biosynthesis, vol. 2, pp. 55-100. Edited by P. N. Campbell and J. S. Sargent. London: Academic Press.

Baglioni, C., Bleiberg, I. \& Zauderer, M. (1971). Assembly of membrane-bound polyribosomes. Nature New Biology 232, 8-12.

Bandyopadhyay, A. K. \& Deutcher, M. P. (197I). Complex of aminoacyl-transfer RNA synthetases. Journal of Molecular Biology 6o, I 13-122.

Beaudet, A. L. \& CASKey, C. T. (I97I). Mammalian peptide chain termination. II. Codon specificity and GTPase activity of release factor. Proceedings of the National Academy of Sciences of the United States of America 68, 619-624.

FAlveY, A. K. \& STAeHElin, T. (1970). Structure and function of mammalian ribosomes. I. Isolation and characterization of active liver ribosomal subunits. Journal of Molecular Biology 53, I-20.

Goldstern, J. L. \& CASkeY, C. T. (I970). Peptide chain termination: Effect of protein S on ribosomal binding of release factors. Proceedings of the National Academy of Sciences of the United States of America $67,537-543$.

Heredia, C. F. \& Halvorson, H. O. (1966). Transfer of amino acids from aminoacyl soluble ribonucleic acid to protein by cell free extracts from yeast. Biochemistry 5, 946-952.

Heywood, S. M. \& Thompson, W. C. (I971). Studies on the formation of the initiation complex in eukaryotes. Biochemical and Biophysical Research Communications 43, 470-475.

Hollomon, D. W. (I969). Biochemistry of germination in Peronospora tabacina (Adam) conidia: Evidence for the existence of stable messenger RNA. Journal of General Microbiology 55, 267-274.

Hollomon, D. W. (1970). Ribonucleic acid synthesis during fungal spore germination. Journal of General Microbiology 62, 75-87.

Hollomon, D. W. (I97I). Protein synthesis during germination of Peronospora tabacina (Adam) conidia. Archives of Biochemistry and Biophysics 145, 643-649. 
JOKLIK, W. K. \& BECKER, Y. (1965). Studies on the genesis of polysomes. II. The association of nascent messenger RNA with the $40 \mathrm{~S}$ subribosomal particle. Journal of Molecular Biology 13, 5I I-520.

KaJI, A., KAJI, H. \& NovelLI, G. D. (I965). Soluble amino acid-incorporating system. I. Preparation of the system and nature of the reaction. Journal of Biological Chemistry 240, I185-I I9I.

LePPiK, R., Hollomon, D. W. \& BotTomLey, W. (1972). Quiesone: An inhibitor of the germination of Peronospora tabacina conidia. Phytochemistry II, 2055-2063.

LOENING, U. E. (1967). The fractionation of high molecular weight ribonucleic acid by polyacrylamide gel electrophoresis. Biochemical Journal 102, 25 I-257.

LOENING, U. E. (1969). The determination of the molecular weight of ribonucleic acid by polyacryla mide gel electrophoresis. The effects of changes in conformation. Biochemical Journal Ir3, I3I-I38.

Lowry, O. H., Rosebrough, N. J., Farr, A. L. \& Randall, R. J. (195I). Protein measurement with the Folin phenol reagent. Journal of Biological Chemistry 193, 265-275.

Lucas-Lenard, J. \& Lipmann, F. (197I). Protein biosynthesis. Annual Review of Biochemistry 40, 409-448.

MARTIN, T. E. \& WoOL, I. G. (I969). Formation of active hybrids from subunits of muscle ribosomes from normal and diabetic rats. Proceedings of the National Academy of Sciences of the United States of America 60, 569-574.

Muench, K. H. \& Berg, P. (I966). Preparation of aminoacyl ribonucleic acid synthetases from Escherichia coli. In Procedures in Nucleic Acid Research, pp. 375-383. Edited by G. L. Cantoni and D. R. Davies. New York: Harper Row.

Munro, H. N. \& FLecK, A. (1966). The determination of nucleic acids. Methods of Biochemical Analysis 14, I I 3-I76.

Obrig, T. G., Culp, W. J., McKeehan, W. L. \& Hardesty, B. (1971). The mechanism by which cycloheximide and related glutarimide antibiotics inhibit peptide synthesis on reticulocyte ribosomes. Journal of Biological Chemistry 246, I74-I8I.

PestKA, S. (1971). Inhibitors of ribosome functions. Annual Review of Microbiology 25, 487-562.

Prichard, P. M., Gilbert, J. M., Shafritz, D. A. \& Anderson, W. F. (1970). Factors for the initiation of haemoglobin synthesis by rabbit reticulocyte ribosomes. Nature, London 226, 5 I I-5I 6 .

Roberts, K. \& Coleman, W. H. (I972). Particulate forms of phenylalanyl-tRNA synthetase from Ehrlich ascites cells. Biochemical and Biophysical Research Communications 46, 206-2 I4.

SCHMOYeR, I. R. \& LOVETT, J. S. (1969). Regulation of protein synthesis in zoospores of Blastocladiella. Journal of Bacteriology 100, 854-864.

SHEPHERD, C. J. \& MANDRYK, M. (1962). Auto-inhibitors of germination and sporulation in Peronospora tabacina Adam. Transactions of the British Mycological Society 45, 233-244.

Sirin, A. S. (1969). Informosomes. European Journal of Biochemistry 10, 20-35.

Strominger, J. L. (1955). Enzymic synthesis of guanosine and cytidine triphosphates. A note on the nucleotide specificity of the pyruvate phosphokinase reaction. Biochimica et biophysica acta 16, 616-618.

VAN EtTen, J. L. \& Brambl, R. M. (1968). Protein synthesis during fungal spore germination. II. Aminoacyl-soluble ribonucleic acid synthetase activities during germination of Botryodiplodia theobromae. Journal of Bacteriology 96, 1042-1048.

YANIV, Z. \& STAPLES, R. C. (I969). Transfer activity of ribosomes from germinating uredospores. Contributions from the Boyce Thompson Institute 24, 157-163.

YANIV, Z. \& StaPLes, R. C. (I97I). The purification and properties of the aminoacyl-tRNA binding enzyme from bean rust uredospores. Biochimica et biophysica acta 232, 717-725. 